2. Бех І. Д. Вибрані наукові праці. Виховання особистості. Чернівці : Букрек, 2015. Т. 1. 840 с.

3. Вишневський О. Теоретичні основи сучасної української педагогіки : посіб. для студ. вищ. навч. закл. Дрогобич : Коло, 2006. 326 с.

4. Гавриш Н. П., Ситник Г. І., Коломієць Н. М. Національне виховання учнів: регіональний аспект (з досвіду роботи загальноосвітніх навчальних закладів Рівненської області). Рівне, 2012. Ч. І. 280 с.

5. Гончаренко С. У. Український педагогічний енциклопедичний словник. 2-е вид., доповн. й випр. Рівне : Волинські обереги, 2011. 552 с.

6. Енциклопедія освіти / головний редактор В. Г. Кремень ; Академія пед. наук України. Київ : Юрінком Інтер, 2008. 1040 с.

УДК 37.018.46+37.015.311

DOI: 10.37026/2520-6427-2020-104-4-114-117
7. Кічук А. Ціннісне ставлення як психологічний феномен. Психологія і суспільство. 2006. № 3. С.80-84.

8. Потапчук Т. В. Феномен ціннісного ставлення особистості студента до себе й оточуючих у наукових дослідженнях. Науковий вісник Національного університету біоресурсів $і$ природокористування України. Серія «Педагогіка. Психологія. Філософія» / редкол. : Ніколаєнко С. М. (відп. ред.) та ін. Київ : Міленіум, 2018. Вип. 220. С.258-266.

9. Ситник Г., Гавриш Н. Методичне забезпечення реалізації Програми національного виховання учнівської молоді Рівненщини на 2008-2020 роки. Методичний вісник. Рівне, 2008. Вип. II. 56 с.

Дата надходження до редакиії: 16.09.2020 p.

\section{Лілія КОВРІГІНА,}

кандидат філологічних наук,завідувач кафедри суспільно-гуманітарних дисциплін КЗ «Житомирський ОІППО» Житомирської обласної ради

Ольга ОРЛОВА,

кандидат педагогічних наук, старший викладач кафедри суспільно-гуманітарних дисииплін КЗ «Житомирський ОІППО» Житомирської обласної ради

\title{
ОСОБЛИВОСТІ САМОВДОСКОНАЛЕННЯ ЯК КАТЕГОРІЇ РОЗВИТКУ ОСОБИСТОСТІ УЧНЯ
}

\begin{abstract}
У статті здійснено категоріальний аналіз поняття особистісного самовдосконалення, окреслено його лексичне значення та розглянуто як сочіально-особистісне явище в контексті усвідомленої взаємодї людини з конкретним соціальним середовищем. Обтрунтовано доповнення поняття «самовдосконалення» означальним терміном «особистісне» та визначено першорядну роль самого суб'єкта щодо актуалізаиї можливостей подальшого системного руху в моделі суспільних відносин. Проаналізовано та уточнено визначення ключової категорії відносно учня базової середньої школи. Окреслено нові внутрішні позииії підлітка та виникнення його особливих потреб. Обтрунтовано актуальність особистісного самовдосконалення учнів саме в ией віковий період. Здійснено порівняльний аналіз рівня психічного та особистісного розвитку молодших школярів та учнів базової середньої школи. Визначено докорінні зміни $i$ співвідношення основних змін у змісті і співвідношенні мотиваиійних тендениій особистості підлітка.

Ключові слова: особистісне самовдосконалення, удосконалення, самоствердження підлітка, самовираження, становлення особистості.
\end{abstract}

The article in the context of the study of the problem defines a categorical analysis of the concept of personal self-improvement. The lexical meaning of the term self-improvement is outlined and considered as a socio-personal phenomenon in the context of conscious human interaction with a particular social environment. The category of personality is characterized and its features are determined. The addition of the concept of «self-improvement» with the defining term «personal» is substantiated and its primary role of the subject in actualizing his own possibilities of further systemic movement in the model of social relations is determined. The definition of the key category in relation to a basic secondary school student is analyzed and clarified. Significant changes in the motivational sphere of his personality, which determines the active mental development of the adolescent. New internal positions and the emergence of special needs have been identified, in particular attempts to overcome the boundaries of school in their self-realization and to join the life and activities of adults. The relevance of personal self-improvement of students of basic secondary school in this age period is substantiated. A comparative analysis of the level of mental and personal 
development of primary school and primary school students. Radical changes and the ratio of the main changes in the content and the ratio of the main motivational tendencies of the adolescent's personality are determined. It is proved that adolescence is sensitive to the development of personal self-awareness. Manifestations of the desire for independence are markedly different in younger and older adolescents. It is substantiated that adolescence is characterized by objective changes in the living conditions of the child, which encourage him to actively try self-education, self-esteem, self-development, self-improvement. Within the limits of the researched problem the characteristic features of pupils of basic secondary school are defined.

Key words: personal self-improvement, improvement, self-affirmation of the teenager, self-expression, formation of personality.

Постановка проблеми. Соціально-економічні та політичні виклики суспільства зумовили ряд реформ у нашій країні, що зміцнюють вплив закладу загальної середньої освіти на особистісний розвиток учня. Особливої значущості в означеному контексті набуває потреба у вихованні активного громадянина, відповідальної, творчої особистості, здатної до самовиховання і самовдосконалення, спроможної самореалізуватися та спрямувати власний потенціал на розвиток суспільства.

Окреслена проблема набуває особливої актуальності в умовах навчально-виховної роботи 3 учнями базової середньої школи. Відомо, що саме в цей період відбувається входження дитини в якісно нову соціальну позицію, в якій формується ііі свідоме ставлення до себе як до члена суспільства. Важлива роль у реалізації поставлених завдань належить педагогу, оскільки саме від його особистісних характеристик залежить якість освітніх послуг, розвиток та становлення учнів як у процесі навчання, так і в позанавчальний час.

Аналіз наукових досліджень і публікацій. Аналіз наукових джерел свідчить, що питання самовдосконалення особистості знайшли відображення в історії зарубіжної (Сократ, Аристотель, Сенека, Квінтіліан, Ж.Ж. Руссо, Й. Г. Пестолоцці, Ф.-А. Дистерверг та ін.) і вітчизняної наукової думки (Г. С. Сковорода, В. О. Сухомлинський, К. Д. Ушинський та ін.).

До наукових розвідок, що засвідчили важливість окресленої проблеми, належать праці відомих науковців, зокрема таких як Г. М. Андрєєва, І. Д. Бех, Л. І. Божович, Л. С. Виготський, А. Й. Капська, А. С. Макаренко, М. Монтессорі, А. В. Мудрик та ін. Сьогодні це питання є предметом дослідження таких сучасних науковців, як О. В. Борденюк, В. М. Гринькова, Н. М. Лосєв, С. Н. Піхота, О. С. Прокопова, О. С. Сисоєва, К. Г. Скворцова, І. А. Чернишова та інші.

Однак, як свідчить аналіз науково-педагогічних джерел, проблема особистісного самовдосконалення учнів $є$ актуальною і вимагає детального дослідження.

Метою статті $\epsilon$ визначення ключової категорії «особистісне самовдосконалення» та уточнення іiі відносно учня базової середньої школи.

Виклад основного матеріалу. Загальні орієнтири наукового обгрунтування терміна «самовдосконалення» окреслюються його лексичним значенням, що походить від поєднання частки «само» та поняття «вдосконалення» або «удосконалення». Так, «само» як спільна частина, що використовується для позначен- ня різних видів самоактивності особистості, вказує на: 1) скерованість дій на самого суб'єкта діяльності; 2) здійснення їх людиною самостійно, без стороннього впливу та будь-якої допомоги; 3 ) їх внутрішню детермінованість, автоматичність здійснення, приведення в дію під впливом внутрішніх механізмів [1, с. 29].

Вживання терміна «удосконалення» свідчить про спрямованість дій на досягнення досконалості як найвищої позитивної мети розвитку особистості, а також підкреслює «вершинність» цієї мети (прагнення досягти вершини розвитку), що простежується 3 огляду етимологічного значення «удосконалення» як «доведення до скону», «до кінця», подібно до російського «усовершенствование» як досягнення «вершини» [6, с. 51-52].

Логіка нашого дослідження вимагає уточнення та визначення поняття «самовдосконалення», що $\epsilon$ усвідомленим, цілеспрямованим, постійним, систематичним, самостійним, багатоаспектним, цілісним, особистісним, індивідуальним, динамічним процесом, що здійснюється осмислено та грунтується на творчому ставленні до себе.

Разом із тим, цю категорію розглядають як явище соціально-особистісне, оскільки вона завжди $є$ результатом усвідомлення взаємодії людини 3 конкретним соціальним середовищем, у ході якого реалізує потребу формування особистісних якостей, що забезпечують успіх у діяльності та загалом у житті.

У розрізі нашого дослідження термін «особистісне самовдосконалення» був доповнений поняттям «особистість», що пов'язане 3 категорією «самовдосконалення» через філософську категорію «самості», яка й визначає численні самопроцеси - самовдосконалення, саморозвиток тощо [7].

Зазначимо, що категорія особистості окреслює особливості, якості, стани індивіда, зумовлені його предметною діяльністю й особистісними комунікативними зв'язками та взаємодіями.

Особистісне самовдосконалення розглядають як оволодіння способами діяльності з урахуванням власних інтересів та можливостей, що відображається у неперервному самопізнанні, розвитку необхідних сучасній людині якостей, формуванні культури мислення та поведінки.

Зважаючи на зазначене вище, можна стверджувати, що особистісне самовдосконалення - це робота над собою, яка передбачає усвідомлений розвиток своїх (власних) здібностей, свідоме прагнення удосконалення свого (власного) особистісного потенціалу, формування здатності до самопізнання, самопроєктування, самореалізації в процесі цілеспрямованої творчої самостійної діяльності та супроводжується прийняттям рішень.

В означеному контексті поняття «особистісного самовдосконалення» потребує уточнення відносно учня базової середньої школи. Враховуючи психолого-педагогічну характеристику зазначеної вікової групи, процес розвитку готовності до особистісного самовдосконалення в умовах загальноосвітньої школи дозволив виділити декілька етапів відповідно до ступенів навчання: початкова школа (молодший шкільний вік), базова середня школа (підлітковий вік), профільна середня освіта (старший шкільний вік).

Базова середня школа, як зазначено у Законі України «Про повну загальну середню освіту», - це один із ступенів загальноосвітньої школи, що забезпечує 
базову загальну середню освіту (5-9 класи) [3, с. 18]. Учнями базової середньої школи є діти середнього шкільного віку від 11-ти до 15-ти років. Цей період у загальній віковій періодизації називається підлітковим або перехідним, оскільки саме в цей час відбувається перехід від дитинства до юності у фізичному, психічному та соціальному аспектах. Особливості розвитку дітей зазначеної вікової групи визначає необхідність розподілу вказаного періоду на дві підгрупи: молодших підлітків 11-12 років та старших підлітків 13-15 років.

Особливістю середнього шкільного віку є увага до анатомо-фізіологічних змін в організмі дитини, зокрема, статевого дозрівання. Інтереси підлітка нестійкі, часто змінюються i, як правило, не пов'язані 3 навчальною діяльністю, хоча нерідко переростають у захоплення. Саме ці зміни істотно позначаються на психічному розвитку його особистості, пізнавальній діяльності та поведінці, стосунках у колективі [4].

На основі вищого, порівняно з молодшими школярами, рівня психічного та особистісного розвитку відбуваються докорінні зміни у змісті і співвідношенні основних мотиваційних тенденцій особистості підлітка. На цьому етапі дитина прагне знайти своє місце у групі ровесників, вийти за межі школи та приєднатися до життя і діяльності дорослих, тобто виникає специфічний комплекс мотивів, що виражається через особливу інтерпретацію поняття «самості» та реалізується через самовираження, самоствердження, саморозвиток, самовдосконалення, самореалізацію [5].

Самовираження дитини підліткового віку відбувається на основі самооцінних особистісних характеристик (емоційний компонент), що саме у цей період виходять на перше місце. Основні переживання підлітка обумовлені фізичною зміною його тіла. Самовираження відбувається через рефлексію на свою зовнішність і тривогу з цього приводу. Переживаючи відповідність або невідповідність еталону, підліток стає нетерпимим до своєї поведінки і до поведінки інших людей. Прагнення до самовираження є головним мотивом поведінки і стимулює пошук засобів до самовираження.

У підлітковому віці спостерігаються тенденції до виникнення потреби у самоствердженні. Це пояснюється постійною взаємодією підлітка з однолітками, що стимулює появу прагнення зайняти належне місце серед них та є одним із домінуючих мотивів поведінки та діяльності. Потреба підлітка в самоствердженні настільки важлива, що задля визнання ровесниками він готовий поступитися своїми поглядами та переконаннями, здійснювати вчинки всупереч своїм моральним поглядам та переконанням.

Здатність до рефлексії на себе та інших як основа розвитку самосвідомості забезпечує процес самоствердження підлітка. Головне питання, яке хвилює дитину цього віку, - хто вона серед інших. У зазначеному контексті іії передусім хвилює власне тіло, особистість, а також ствердження через реалізацію своїх домагань та визнання, через своє ім'я, задоволення потреби у своїй «самості» (унікальності), потреби бути і вважатися дорослим. Почуття дорослості $є$ найважливішою формою прояву самосвідомості підлітків, що відображає нову життєву позицію стосовно себе, людей та світу.

Підлітковий вік $є$ сенситивним для розвитку самосвідомості особистості. У підлітків виникає інтерес до себе та якостей своєї особистості, потреба оцінити, порівняти себе з іншими, розібратися у своїх почуттях і переживаннях. На основі розвитку самосвідомості, зростання вимог до себе, пошуку власного місця серед ровесників і старших у них 3'являється прагнення до самовдосконалення, проте порівняно невеликий життєвий досвід і ще несформований життєвий світогляд нерідко породжують суперечності між потребою у самовдосконаленні і невмінням його реалізувати [5].

Саме у цьому віці, здійснюючи рефлексію на себе, дитина докладає зусиль до становлення себе як особистості. При цьому характерна інтенсифікація розвитку одночасно у двох напрямах:

- прагнення визначити своє місце в соціумі, освоєння й оволодіння всім діапазоном соціального простору;

- прагнення до рефлексії на свій внутрішній, інтимний світ через самозаглиблення й відокремлення від однолітків, близьких.

Не всі підлітки проходять шлях становлення особистості, що й визначає наявність двох його рівнів: нижній рівень - інфантильні діти, підлітки за віком, верхній - ті, хто символізує потенційні можливості віку, можуть успішно орієнтуватися в цінностях i, володіючи розвиненою рефлексією, свідомо шукати власне рішення будь-якої соціально значущої проблемної ситуації. Саме такі підлітки виявляються потенційно здатними до самовдосконалення.

Потребнісно-мотиваційна сфера цієї групи підлітків характеризується перевагою пізнавального інтересу як основного мотиву поведінки і діяльності. За таких умов навчальні й позанавчальні інтереси пов'язані між собою та утворюють стійку структуру. Змінюються уявлення про ідеали: від розуміння ідеалу як змістового зразка або образу конкретної людини - до характеристики його основного життєвого принципу як способу самоздійснення (самореалізації) особистості [5].

Формування ставлення підлітка до себе як особистості відбувається у два етапи, що відповідають молодшому і старшому періодам підліткового віку. На першому етапі відбувається усвідомлення своєї відмінності від ровесників, утвердження належності до світу дорослих. Цьому періоду властиві некритичне наслідування зовнішніх манер дорослих, відчутна залежність від групи ровесників. На другому етапі підліток уже не сумнівається, що він не дитина, починає усвідомлювати своєрідність своєї особистості, знижується його залежність від групи однолітків. Якщо ровесники змушують підлітка чинити всупереч його уявленням про себе, він може не погодитися 3 ними, відстояти свою думку. Старшого підлітка характеризують підвищена увага до внутрішнього світу інших людей, до самоаналізу, поява здатності до самовдосконалення [5].

Усвідомлення і становлення образу «Я» і потребнісно-мотиваційної сфери пронизує розвиток моральної сфери підлітка як основи самостійного і самодостатнього поводження. Однією із форм індивідуальної свідомості, що належить до психічних новоутворень віку, є моральна свідомість, структуру якої визначає: знання моральних норм, ставлення до них, моральна самооцінка, цілепокладання. Критерієм сформованості моральної свідомості є моральний учинок. Учинки підлітка у всіх сферах його життєдіяльності (навчання, спілкування, пошук засобів самовираження) 
пояснюються визнанням ним відповідальності, а не схваленням, як це було у молодшого школяра.

Прояви прагнення до самостійності помітно відрізняються у молодших і старших підлітків.
У поведінці перших ще переважають дитячі риси, їх цікавить передусім зовнішній бік життя дорослих та враження, яке їх учинки справляють на інших. Самі вчинки часто бувають імпульсивними й безконтрольними (див. табл.) [2, с. 85].

Табличя

Етапи підліткового періоду

\begin{tabular}{|c|l|l}
\hline $\begin{array}{c}\text { Етапи } \\
\text { підліткового } \\
\text { періоду }\end{array}$ & \multicolumn{1}{|c|}{ Особливості поведінки, діяльності } & \multicolumn{1}{|c}{ Мотивація вчинків } \\
\hline I & $\begin{array}{l}\text { Наслідування ровесників і старших, відтворювальна } \\
\text { діяльність }\end{array}$ & Поверхнева та ситуативна \\
\hline II & Активний розвиток інтересу до себе як особистості & Диференційована \\
\hline III & $\begin{array}{l}\text { Саморегуляція поведінки як складова частина } \\
\text { самовиховання }\end{array}$ & $\begin{array}{l}\text { Постає як регулятор поведінки і } \\
\text { діяльності особистості }\end{array}$ \\
\hline
\end{tabular}

На першому етапі підліткового періоду мотивування вчинків і діяльності $є$ відтворювальним Підлітки прямо наслідують ровесників і старших, а отже, мотивація власних учинків $є$ поверховою та ситуативною. Із настанням другого періоду у підлітків загострюється й активно розвивається інтерес до своєї особистості. Вони прагнуть ствердитися в товаристві ровесників, стають небайдужими до оцінок їх особистості значущими іншими, очікують, що ці оцінки будуть тотожними їх самооцінці. Значно диференційованішою $є$ їх мотивація вчинків. На третьому етапі головне значення має саморегуляція поведінки як складова частина самовиховання, а мотивація вчинків постає як регулятор поведінки і діяльності особистості [5].

Таким чином, підлітковий вік характеризується поступовим підвищенням мотиваційної діяльності та зростанням інтересу до себе як особистості.

У молодших підлітків самооцінка практично несформована, вони ще недостатньо усвідомлюють власні дії. У зв'язку з відсутністю досвіду підлітки часто не визнають очевидної провини, намагаючись за будь-яких умов виправдатися. Проблема полягає в тому, що їм досить важко визнати свою провину публічно, оскільки це рівноцінно руйнуванню власної особистості. Водночас вони, як правило, розуміють і глибоко переживають ту чи іншу ситуацію.

Ставлення старших підлітків до своїх учинків більш свідоме. Вони схильні до самоаналізу, хоча не завжди здатні справитися з ним. Старших підлітків цікавить не лише зовнішній бік життя дорослих, але і їх внутрішній світ, духовні якості [2, с. 85].

Судження молодших підлітків про себе відображаються в оцінці їх взаємин $з$ іншими людьми. Таке оцінювання стосується вміння дружити, прояву чуйності до інших людей, своєї поведінки серед інших, поваги до себе, сприймання однокласниками, що свідчить про досить високий рівень самосвідомості, збагачення досвіду соціальної поведінки.

Самооцінка старших підлітків є досить різноманітною та узагальненою за змістом. Якостей, які вони усвідомлюють, приблизно удвічі більше, ніж у молодшій підлітковій групі. Старші підлітки оцінюють не лише окремі риси характеру, але й свою особистість загалом, виявляють певну соціальну зрілість, усвідомлюють себе готовими до життя особистостями [5].
Висновки. Отже, підлітковий вік характеризується об'єктивними змінами в житті дитини, які спонукають іiі до активних спроб самовиховання, самооцінки, саморозвитку та самовдосконалення.

Зазначене вище дає підстави стверджувати, що характерними особливостями учнів основної школи у межах досліджуваної проблеми є:

- усвідомлення єдності й цілісності власної психологічної організації як основа особистісного саморозвитку;

- яскраво виражені особливості спонтанного саморозвитку;

- сформована домінанта самовдосконалення.

Таким чином, у публікації доведено, що підлітковий вік у цілому є сенситивним періодом для запуску механізму особистісного самовдосконалення учнів, на що й повинна спрямовуватися діяльність учителя. Проте запропонований аналіз не вичерпує всіх актуальних питань досліджуваної проблеми.

\section{СПИСОК ВИКОРИСТАНОЇ ЛІТЕРАТУРИ}

1. Словник української мови / за ред. І. К. Білодіда. Київ : Наукова думка, 1978. Т. 9. С. 29.

2. Заброцький М. М. Основи вікової психології : навчальний посібник. Тернопіль : Навчальна книга Богдан, 2008. С. 85.

3. Про повну загальну середню освіту : Закон України. Ст. 4. URL: https://zakon.rada.gov.ua/laws/sh ow/463IX?fbclid=IwAR2P5cmsmci9nuhurRKHgML4w 56IiAr-kMhFkaPOScLtlgAvUNL2p2u-QCc\#Text (дата звернення: 10.09.2020).

4. Максименко С. Д. Загальна психологія. Київ : Межрегіональна академія управління персоналом, 2000. 256 c. URL: http://www.bookshunt.ru/b232949 zagalna psihologya 19.11.2211 21.30 (дата звернення: 11.09.2020).

5. Савчин М. В. Вікова психологія : навч. посібник. 2-е видання, доповн. Київ : Академвидав, 2011. 368 c. URL: http://academia-pc.com.ua/product/78. 19.11.2011 (дата звернення: 05.09.2020).

6. Шестакова Т. В. Формування готовності майбутніх педагогів до професійного самовдосконалення : дис. ... канд. пед. наук : 13.00.04. Київ, 2006. С. 51-52.

7. Фрейджер Р. Фейдимен Дж. Теории личности и личностный рост. URL: http://www.gumer.info/bibliotek Buks/Psihol/freydjer/index.php. (дата звернення: $1 \overline{2} .09 .2011)$.

Дата надходження до редакиії: 22.10.2020 р. 